\begin{tabular}{|c|c|c|}
\hline ב & International Journal of Current Research in & \\
\hline & Biosciences and Pla & \\
\hline $\mathrm{BL}$ & $\begin{array}{r}\text { ISSN: 2349-8080 (Online) } \bullet \text { Volume } 3 \bullet \text { Number } 11 \\
\text { Journal homepage: www.ijcrbp.com }\end{array}$ & \\
\hline
\end{tabular}

\title{
Effects of Chlorophyll Contents of Greengram Varieties /Lines as Influenced by Root-knot Nematode, Meloidogyne incognita
}

\author{
Ritu Kumari Padey', D. K. Nayak² and Rajesh Kumar Kar³
}

${ }^{1}$ Final year M.Sc. (Agri.) Nematology Student, Department of Nematology, Orissa University of Agriculture and Technology, Bhubaneswar-751 oo3, Odisha, India

${ }^{2}$ Associate Professor, Department of Nematology, Orissa University of Agriculture and Technology, Bhubaneswar-751 oo3, Odisha, India

3Final year M.SC (Agri.), Department of Plant Breeding and Genetics, Orissa University of Agriculture and Technology, Bhubaneswar-751 oo3, Odisha, India

*Corresponding author.

\begin{abstract}
A bstract
A study was undertaken in greengram [Vigna radiata (L.) Wilezek] varieties to assess biochemical changes of resistant and susceptible cultivars due to the root-knot nematode infection. The changes in nutrient profile in plants inoculated with nematodes caused reduction in chlorophyll contents. Chlorophyll 'a' was maximum decreased (96.36\%) in resistant check variety 7 GGG $10-14$ followed by $93.98 \%$ in susceptible check variety 28 PM 10-12 but increasing trend was observed from 7.31 to $28.30 \%$ in 24ML-233 and 17 IPM 9901-6 varieties respectively. Chlorophyll 'b' was maximum decreased $(61.81 \%)$ in susceptible check variety 29 PUSA-0672 followed by $53.33 \%$ in resistant check variety 7 GGG $10-14$ but increasing trend was observed from 3.031 to $76.66 \%$ in 24ML-233 and 17 IPM 9901-6 varieties respectively. Total chlorophyll was maximum decreased $(54.92 \%)$ in susceptible check variety 29 PUSA-0672 followed by $32.79 \%$ in susceptible check variety 28 PM10-12 but increasing trend was observed from 6.031 to $86.27 \%$ in 24ML-233 and 17 IPM 9901-6 varieties respectively.
\end{abstract}

\section{Introduction}

Greengram is commonly known as mung bean or moong [Vigna radiata (L.) Wilezek] is an important pulse crop next to chickpea and pigeon pea in India. Being one of the major pulse crop of the Fabaceae family it is a rich source of dietary protein $(22.9 \%)$, carbohydrate $(62.8 \%)$, fat $(1.2 \%)$, minerals (3\%) and fibre (1\%) and also it has considerable amount of calcium $105 \mathrm{mg}$, phosphorous $330 \mathrm{mg}, \mathrm{Fe}$, ashes, etc. The major causes of low productivity are the incidence of insects and diseases including plant parasitic nematodes. Plant parasitic nematode, Meloidogyne incognita alters the metabolic processes of the host which are manifested in the form of cellular, physiological and biochemical changes occurring in the infected host. The root-knot nematodes cause measurable changes in the morphology and physiology of the host plants (Williamson and Gleason, 2003). As a result of Meloidogyne infection, amounts of chlorophyll pigment, protein and oil contents are being changed. Reduction in chlorophyll content of the infected plants has been reported by Vashishth et al. 
(1994), Poornima and Vadivelu (1998), Ramakrishna and Rajendran (1998) and Parveen et al. (2006).

The response of Vigna radiata regarding the biochemical attributes was significant at various nematode treatments. The growth of the plant responded negatively towards the lower as well as higher inoculum levels of $M$. incognita. Decrease in all these parameters including plant growth, leaf area, chlorophyll, seed protein, nitrogenase activity and leghaemoglobin due to increased in number of the nematode. The root knot nematode infection often reduces plant growth and yield (Sasser and Freckman, 1987; Williamson, 1998) and decreases nutrient uptake (Patel et al., 1988) and infested plants showed deficiencies of $\mathrm{N}, \mathrm{Mg}, \mathrm{Fe}, \mathrm{B}, \mathrm{Cu}$ and $\mathrm{Zn}$ (Good, 1968) due to root damage by $\mathrm{RKN}$ and subsequent prevention of water and nutrient uptake by the roots (Gaillaud et al., 2008).

All anatomical malformations and physiological malfunctions contributed in suppressing the plant growth and yield (Hussey, 1985). Doney et al. (1970) observed the functioning of nodules by altering host nutrition and leghaemoglobin content which was confirmed by a group of scientists(Sharma and Sethi, 1975; Chahal and Singh, 1984) and bacteroid population, content of nodules (Barker et al., 1972; Ali et al., 1981).They reported that after 45 days the total chlorophyll content showed significant interaction between Rhizobium and nematode inoculation and at harvest there was no significant interaction. Chahal and Chahal (1987a) studied the effect of different levels of M.incognita on Vigna radiata cv. G-65 and found that nematode caused reduction in the chlorophyll content of leaves which adversely affected the functioning of nodules. Increase of total chlorophyll ' $a$ ' and 'b' content was observed by Verma et al. (1996) on mungbean at all inoculation levels of root-knot nematode with growth period up to 30 days whereas decrease of the same was noted again on $45^{\text {th }}$ day of inoculation.

At all the growth stages of the plant with the nematode levels ranging from 100 to $1000 \mathrm{~J} 2 /$ plant the contents were found to be increased. Jaiswal and Sing (2008) observed that chlorophyll a, b and total chlorophyll contents were significantly decreased with an increase in nematode inoculum levels and was minimum at 10,000 and 5000 nematodes/plant followed by 1000 and 100 nematodes/plant.

Melakeberhan et al. (1985) reported that total chlorophyll and chlorophyll- a content in Phaseolus vulgaris plants infected with different levels of $M$. incognita, decreased significantly with increased levels of infestation at 3 weeks after inoculation (45 DAS).

Vaishnav et al. (1985) observed that the chlorophyll a, b and total fractions decreased by $75.7,79.4$ and $76.7 \%$ in comparison to control 60 days after inoculation in peanut plants infected by $M$. arenaria. Pathak et al. (1990) observed an increase in leaf chlorophyll ' $a$ ' and ' $b$ ' at 45 and 90 days after sowing in wheat cv. HD-1533 infected with Anguina tritici. They also found that the chlorophyll ' $a$ ' fraction of the leaf decreased at initial stage (20 days) and later on the accelerated growth of infected plants was correlated with increased percentage of chlorophyll.

Nayak (2006) reported chlorophyll ' $a$ ' content of infected brinjal leaves of Pusa Kranti (MR) varieties was reduced from $2.70 \mathrm{mg} / \mathrm{g}$ to $2.010 \mathrm{mg} / \mathrm{g}$. Similarly, in other varieties like Kantabaigan (R) and Pusa Purple Long (HS), chlorophyll 'a' content also reduced. Further, he reported that chlorophyll ' $b$ ' and total chlorophyll content were reduced in the infected leaves of brinjal varieties.

\section{Materials and methods}

\section{Chlorophyll estimation of leaf}

In order to understand the basis of nematode resistance six varieties/ lines of pulses were taken for observation. Out of six varieties 4 resistant checks were 24 ML-233,7 GGG 10-14,17 IPM 9901-6 and8 GM 04-02 and two susceptible checks were 28 PM 10-12 and 29 PUSA 0672 included obtained from Indian Institute of Pulses Research, Kanpur were grown in earthen pots in the greenhouse of Department of Nematology, C.A, Orissa University of Agriculture and Technology, in earthen pots of $15 \mathrm{~cm}$ height $\times 15 \mathrm{~cm}$ dia, sterilized with formaldehyde solution (1.0\%) and filled with autoclaved soil (15 lbs/20min). Pots were arranged on green house benches in Complete Randomised Block Design with three replications according to the treatments. The water used for irrigation purpose was passed through a 500 mesh sieve before use. The soil to be filled in the pots was pulverised, mixed with NPK fertilizers @ 20:40:40 per hectare basis and filled in to the pots @ $1 \mathrm{~kg} /$ pot. The surface sterilized seeds were sown @ 5 to 10 seeds per pot. Each variety was replicated 3 times.

Watering was done regularly, 10 to 12 days after sowing, the plants were thinned keeping one seedling per pot. A small glass tube ( $2 \mathrm{~cm}$ long, $0.5 \mathrm{~cm}$ bore) was inserted 
into the soil near the base of each of the healthy seedlings. Three weeks after seedling emergence axenised nematodes were counted under a stereoscopic microscope and released into the holes after removal of the glass tube @ $1000 \mathrm{~J}_{2} \pm 20$ per seedling in $10 \mathrm{ml}$. Sterile water. For chemical analysis two sets of plants were maintained, one for the uninoculated control (Healthy) and the other infected with the nematode (I). Each set was arranged on separate platforms in the green house in order to avoid cross infection.
One hundred fifty mg leaf portion of each treatment was cut from the composited leaves and were immersed in $50 \mathrm{ml}$ of $80 \%$ acetone in a conical flask and kept in dark for $24 \mathrm{hrs}$ for extraction of chlorophyll from the leaf samples. Thereafter, the chlorophyll extracts were filtered through Whatman No.1 filter paper. Absorbance of the chlorophyll extract was measured at $645 \mathrm{~nm}$ and $663 \mathrm{~nm}$ using a colorimeter. The amount of chlorophyll-a, chlorophyll-b and total chlorophyll were calculated in $\mathrm{mg} / \mathrm{g}$ fresh weight according to the following equations.

i) Chlorophyll-a $(\mathrm{mg} / \mathrm{g}$ fresh weight of leaf $)=12.7 \times(\mathrm{D}-663)-2.69 \times(\mathrm{D}-645) \times \frac{\mathrm{V}}{1000 \times \mathrm{W}}$

ii) Chlorophyll-b $(\mathrm{mg} / \mathrm{g}$ fresh weight of leaf $)=22.9 \times(\mathrm{D}-645)-4.68 \times(\mathrm{D}-663) \times \frac{\mathrm{V}}{1000 \times \mathrm{W}}$

iii) Total chlorophyll $(\mathrm{mg} / \mathrm{g}$ fresh wt. of leaf $)=20.2 \times(\mathrm{D}-645)+8.02 \times(\mathrm{D}-663) \times \frac{\mathrm{V}}{1000 \times \mathrm{W}}$

Where,

D $-645=$ optical density at $645 \mathrm{~nm}$.

D-663= optical density at $663 \mathrm{~nm}$.

$\mathrm{V}=$ final volume of $80 \%$ acetone chlorophyll extract in $\mathrm{ml}$.

$\mathrm{W}=$ Fresh weight in $\mathrm{g}$ of corresponding amount of fresh leaves used in the extraction of chlorophyll.

\section{Results and discussion}

In order to know the chemical and genetic basis of resistance, six varieties were grown with utmost care, both in inoculated and control conditions.

\section{Effect of the nematode infections on chlorophyll ' $a$ ', 'b' and total content}

In the experiment from Table 1, it was observed that the chlorophyll ' $\mathrm{a}$ ' content reduced from $1.33 \mathrm{mg} / \mathrm{g}$ to 0.08 $\mathrm{mg} / \mathrm{g}$ and $1.38 \mathrm{mg} / \mathrm{g}$ to $0.66 \mathrm{mg} / \mathrm{g}$ due to nematode infection in varieties 28 PM $10-12$ and 29 PUSA 0672 respectively. Similarly in the varieties 24 ML-233, 7 GGG 10-14, 17 IPM 9901-6 and 8 GM 04-02 chlorophyll ' $a$ ' reduced from 0.82 to $0.88,1.10$ to 0.04 , 0.06 to 1.36 and 1.41 to $1.43 \mathrm{mg} / \mathrm{g}$ respectively.

In case of chlorophyll ' $b$ ' content reduction from healthy to infected plants recorded were 0.53 to $0.36,0.55$ to $0.21,0.33$ to $0.34,0.45$ to $0.21,0.30$ to 0.53 , and 0.60 to $0.54 \mathrm{mg} / \mathrm{g}$ respectively in case of varieties $28 \mathrm{PM} 10-12$ ,29 PUSA 0672, 24 ML-233, 7 GGG 10-14, 17 IPM 9901-6 and 8 GM 04-02 (Table 1).

Similarly the total chlorophyll content was decreased from 1.86 to $1.25 \mathrm{mg} / \mathrm{g}$ in $28 \mathrm{PM} 10-12,1.93$ to 0.87 $\mathrm{mg} / \mathrm{g}$ in 29 PUSA $0672,1.55$ to $0.71 \mathrm{mg} / \mathrm{g}$ in 7 GGG 10 -

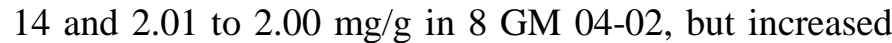
from 1.16 to $1.23 \mathrm{mg} / \mathrm{g}$ in $24 \mathrm{ML}-233$ and 1.02 to 1.90 $\mathrm{mg} / \mathrm{g}$ in 17 IPM 9901-6. Hence nematode caused 32.79 per cent reduction in total chlorophyll content of $28 \mathrm{PM}$ $10-12,54.92$ per cent reduction in 29 PUSA 0672, 54.19 per cent reduction in 7 GGG 10-14, 0.49 per cent reduction in $8 \mathrm{GM} \mathrm{04-02}$ and 6.03 per cent increase in 24 ML-233 and 86.27 per cent increase in 17 IPM 99016 (Table 1 ) (Fig. 1).

During the investigation, decreased chlorophyll content of both chlorophyll 'a', 'b' and total chlorophyll was noticed in the leaves of greengram varieties. However, the decrease was non-significant in resistant varieties which clearly indicated that the reduction of chlorophyll is restricted in inoculated resistant varieties as compared to susceptible variety. Similar results were also reported by Vaishnav et al. (1985) and Tyagi and Alam (1990). Decrease in chlorophyll content may possibly due to the alteration of host nutrition and physiology by nematode infection. Root-knot nematode infection leads to the reduced photosynthetic ability of the plants by combining reduction in leaf chlorophyll contents (Ferguson, 1984). 
Table 1. Reduction in chlorophyll content (a, b, total) in greengram varieties due to the infection of root-knot nematode.

\begin{tabular}{|c|c|c|c|c|c|c|c|c|c|c|c|c|c|}
\hline \multirow[b]{3}{*}{$\begin{array}{l}\text { Sl. } \\
\text { No. }\end{array}$} & \multirow[b]{3}{*}{ Variety } & \multicolumn{4}{|c|}{ Chlorophyll 'a' content mg/g leaf } & \multicolumn{4}{|c|}{ Chlorophyll 'b' content $\mathrm{mg} / \mathrm{g}$ leaf } & \multicolumn{4}{|c|}{ Total chlorophyll content $\mathrm{mg} / \mathrm{g}$ leaf } \\
\hline & & \multicolumn{3}{|c|}{ Infected Healthy Mean } & \multirow{2}{*}{$\begin{array}{l}\% \text { increase }(+) / \\
\text { decrease }(-) \\
\text { over control }\end{array}$} & \multirow{2}{*}{$\begin{array}{l}\text { Infected } \\
\text { Leaf }\end{array}$} & \multirow{2}{*}{$\begin{array}{l}\text { Healthy } \\
\text { Leaf }\end{array}$} & \multirow{2}{*}{ Mean } & \multirow[b]{2}{*}{$\begin{array}{l}\% \text { increase }(+) / \\
\text { decrease }(-) \text { over } \\
\text { control }\end{array}$} & \multirow{2}{*}{$\begin{array}{l}\text { Infected } \\
\text { Leaf }\end{array}$} & \multirow{2}{*}{$\begin{array}{l}\text { Healthy } \\
\text { Leaf }\end{array}$} & \multirow{2}{*}{ Mean } & \multirow{2}{*}{$\begin{array}{l}\text { \% increase } \\
(+) / \text { decrease } \\
(-) \text { over } \\
\text { control }\end{array}$} \\
\hline & & Leaf & Leaf & Leaf & & & & & & & & & \\
\hline 1 & 28 PM 10-12(S) & 0.08 & 1.33 & 0.71 & -93.98 & 0.36 & 0.53 & 0.45 & -32.07 & 1.25 & 1.86 & 1.57 & -32.79 \\
\hline 2 & 29 PUSA 0672(S) & 0.66 & 1.38 & 1.02 & -52.17 & 0.21 & 0.55 & 0.38 & -61.81 & 0.87 & 1.93 & 1.4 & -54.92 \\
\hline 3 & $24 \mathrm{ML}-233(\mathrm{R})$ & 0.88 & 0.82 & 0.85 & 7.31 & 0.34 & 0.33 & 0.34 & 3.03 & 1.23 & 1.16 & 1.19 & 6.03 \\
\hline 4 & 7 GGG 10-14(R) & 0.04 & 1.10 & 0.57 & -96.36 & 0.21 & 0.45 & 0.33 & -53.33 & 0.71 & 1.55 & 1.13 & -54.19 \\
\hline 5 & 17 IPM 9901-6(R) & 1.36 & 1.06 & 0.71 & 28.30 & 0.53 & 0.30 & 0.42 & 76.66 & 1.90 & 1.02 & 1.46 & 86.27 \\
\hline \multirow[t]{3}{*}{6} & 8GM 04-02(R) & 1.43 & 1.41 & 1.42 & 1.41 & 0.54 & 0.60 & 0.57 & -10 & 2.00 & 2.01 & 2.01 & -0.49 \\
\hline & $\operatorname{SEM}( \pm)$ & 0.27 & 0.22 & & & 0.2 & 0.27 & & & 0.39 & 0.39 & & \\
\hline & $\mathrm{CD}(0.05)$ & 0.85 & 0.68 & & & 0.63 & 0.86 & & & 1.22 & 1.25 & & \\
\hline
\end{tabular}

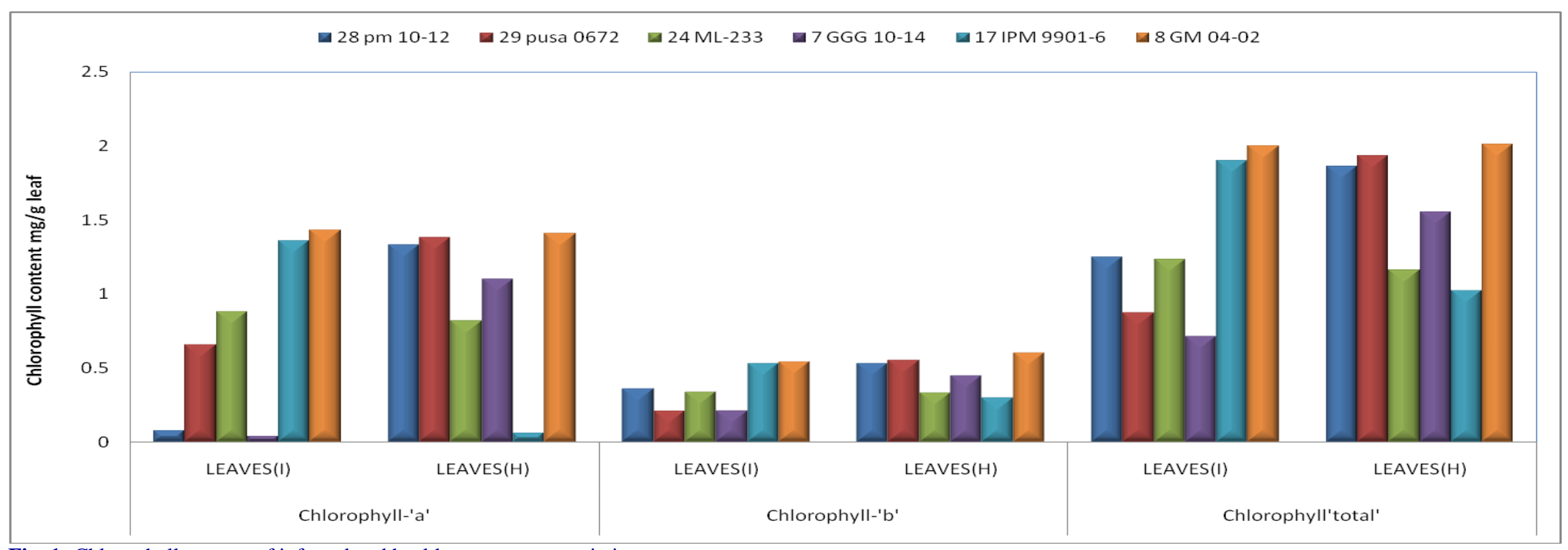

Fig. 1: Chlorophyll content of infected and healthy greengram varieties. 


\section{Conclusion}

Some selective changes occur in the metabolism either as a consequence of the establishment of a compatible (susceptible) host-pathogen interaction or as a result of incompatibility (resistant) between host and parasite .There is some knowledge of biochemical changes that occurs in plants following nematode attack that has not been extended to an overall interpretation of the defense mechanism. The root-knot nematode develops a sophisticated interrelationship with the roots of their host where they induce specific types of nurse cell system. During investigation, the decreased chlorophyll content of both a, b, and total was non-significant in resistant varieties due to alternation of nutrition and physiology of the plants by the nematode infection but among the tested varieties maximum increase in chlorophyll ' $a$ ', ' $b$ ' and total in the variety 7 IPM 9901-6 was $28.30 \%$, $76.66 \%$ and $86.27 \%$ respectively.

\section{Conflict of interest statement}

Authors declare that they have no conflict of interest.

\section{Acknowledgement}

Authors are thankful to those who helped in the chemical analysis of plant samples for different parameters, Project Co-ordinator and Principal Scientist (Nematology), IIPR, Kanpur for providing seed materials to conduct this investigation.

\section{References}

Ali, M. A., Trabulsi, I.Y., Abd-Elsamea, M. E., 1981. Antagonistic interactions between Meloidogyne incognita and Rhizobium leguminosarum on cowpea. Plant Dis. 65, 432-435.

Barker, K.R., Huising, D., Johnston, S.A., 1972. Antagonistic interaction between Heterodera glycines and Rhizobium japonicum on soybean. Phytopathol. 62, 1201-1205.

Chahal, P.P.K., Chahal, U.P.S., 1987. Adverse effect of Meloidogyne incognita on the functioning of nodules of mungbean (Vigna raiata). Nematol. Mediter. 15(1), 13-19.

Chahal, P.P.K., Singh, I., 1984. Effect of population density of Meloidogyne incognita on pea in association with Rhizobium leguminosarum. J. Res. Punjab Agric. Univ. 21, 311-315.

Doney, D. L., Fife, J. M., Whitney, E. D., 1970. The effect of the sugarbeet nematode Heterodera schachtii on the free amino acids in resistant and susceptible beta species. Phytopathol. 60, 1727-1729.

Ferguson, I. B., 1984. Calcium in plant senescence and fruit ripening. Plant Cell Environ. 7, 477-489.
Gaillaud, M. C., Dubreuil, G., Quentin, M., Perfus-Barbeoch, L., Lecomte, P., 2008. Root-knot nematodes manipulate plant cell functions during a compatible interaction. J. Plant Physiol. 165, 104-113.

Good, J. M., 1968. Relation of plant parasitic nematodes to management practices. In: Tropical Nematology (Eds.: Smart, G.C., Perry, V. G.). University of Florida Press, Gainesville. pp.113-138.

Hussey, R. S., 1985. Host-parasite relationships and associated physiological changes. In: An Advanced Treatise on Meloidogyne Biology and Control (Eds.: Sasser, J. N., Carter, C. C.). International Meloidogyne Project, North Carolina State University Graphics, Raleigh, North Carolina. pp.144-153.

Jaiswal, B.K., Singh, U.S., 2008. Pathogenicity of lesion nematode, Pratylenchus zeae and effect on chlorophyll content in maize. Indian J. Nematol. 38(2), 252-254.

Melakeberhan, H., Brooke, R. C., Webster, J. M., Auria, J. M., 1985. The influence of $M$. incognita on the growth, physiology and nutrient content of Phaseolus vulgaris. Physiol. Plant Pathol. 26(3), 259-266.

Nayak, D. K., 2006. Biochemical evaluation of various metabolites as influenced by root-knot nematode, M.incognita in susceptible and resistant brinjal cultivars. Ph.D. thesis submitted to the Orissa University of Agriculture and Technology, Bhubaneswar.

Parveen, K., Haseeb, A., Shukla, P.K.I., 2006. Pathogenic potential of Meloidogyne incognita on Mentha arvensis cv. Gomti. Indian J. Nematol. 36, 177-180.

Patel, D. J., Patel, B. A., Chavda, J. C., Patel, H. V., 1988. Record of Meloidogyne javanica on groundnut in Gujarat, India, Int. Arachis Newslett. 3, 16-17.

Pathak, N., Ray, S. N., Nath, R. P., Sharma, S. G., 1990. Effects of Anguina tritici infection of the photosynthetic pigments of wheat. Curr. Nematol. 1(1), 15-18.

Poornima, K., Vadivelu, S., 1998. Pathogenisity of Meloidogyne incognita to turmeric (Curcuma longa L.). Proceedings of the 3rd International Symposium of AfroAsian Society of Nematologists, Sugarcane Breeding Institute,Coimbatore, April 16-19, 1998. pp.29-31.

Ramakrishnan, S., Rajendran, G., 1998. Effect of individual and concomitant initial inoculum of Meloidogyne incognita and Rotylenchulus reniformis on growth, physiology and nutrient content of papaya (Carica papaya L.). Proceedings of the 3rd International Symposium of Afro-Asian Society of Nematologists, Sugarcane Breeding Institute , Coimbatore, April 16-19, 1998. pp.17-28.

Sasser, J.N., Freckman, D., 1987. A world perspective on nematology: The role of society. In: Vistas on Nematology (Eds.: Veech, J., Dickson, D. W.). Society of Nematologists, Hyattsville, Maryland. pp.7-14.

Sharma, N. K., Sethi, C. L., 1975. Effect of initial inoculum level of Meloidogyne incognita and Heterodera cajani on cowpea and on their population development. Indian $\mathbf{J}$. Nematol. 154, 148-154.

Tiyagi, S. A., Alam, M. M., 1990. Effect of root-knot, 
reniform and stunt nematodes on plant growth, water absorption capability and chlorophyll content on chickpea. Int. Chickpea Newslett. 5, 40-42.

Vaishnav, M. U., Patel, H. R., Dhruj, I. U., 1985. Pathogenicity of Meloidogyne arenaria on Arachis hypogaea, Indian J. Nematol. 15(2), 235-236.

Vashishth, K., Fazal, M., Imran, M., Raza, M. M. A., Siddiqui, Z. A., 1994. Morphological and biochemical response of blackgram cultivars of Meloidogyne incognita. J. Ann.
Plant Prot. Sci. 2, 13-18.

Verma, K.K., Gupta, D. C., Sandhooja, J. K., 1996. Physiology changes in mung (Vigna radiata) by $M$. javanica. Indian J. Nematol. 26(2), 250-253.

Williamson, V. M., 1998. Root-knot nematode resistance genes in tomato and their potential for future use. Annu. Rev. Phytopathol. 36, 277-293.

Williamson, V. M., Gleason, C. A., 2003. Plant-nematode interactions. Curr. Opinion Plant Biol. 6(4), 327-333.

\section{How to cite this article:}

Padey, R. K., Nayak, D. K., Kar, R. K., 2016. Effects of chlorophyll contents of greengram varieties /lines as influenced by root-knot nematode, Meloidogyne incognita. Int. J. Curr. Res. Biosci. Plant Biol. 3(11), 17-22. doi: http://dx.doi.org/10.20546/ijcrbp.2016.311.003 